\title{
Islamic Education Teaching Practice Based on the Cultural Diversity of Students
}

\author{
Noraini Omar \\ Mohd Aderi Che Noh \\ Fakulti Pendidikan Universiti, Kebangsaan Malaysia \\ aderi@ukm.edu.my
}

Doi:10.5901/ajis.2015.v4n1s1p135

\begin{abstract}
The teaching of Islamic Education is not only meant to convey the contents of the curriculum of Islamic Education, but actually to establish students' good character, and practicing the skills presented in the classroom. It should be noted that, classrooms consisting of students from various cultures can be challenging for teachers to provide teaching and learning. In this case, the teacher must meet the needs of each student so that they get a fair education. Therefore, the sensitivity of the teachers and their skills in the delivery of education require the appropriate use of approaches, strategies, methods and techniques. Approaches are direct or indirect, teacher-centred or students-centred strategies. This article briefly explores the concept of teaching based on the cultural diversity of students be it the languages, practices, beliefs or values held by students. This is because teachers' understanding of the concept of cultural diversity of students will help them provide the appropriate teaching materials. Thus this preliminary study aims to analyze and provide recommendations based on literature research on how the teaching based on the diversity of students can be implemented in the teaching of Islamic Education. It is hoped that this article can serve as a guide in realizing teaching based on cultural diversity.
\end{abstract}

Keywords: Islamic Education, Islamic Education teaching, Cultural diversity

\section{Introduction}

The Quran specifically laid the foundation that human diversity is to stimulate and promote the occurrence of interaction, cooperation and complimentarily rather than isolation or conflict. In fact, Islam has emphasized its followers to be fair to all, regardless of ethnicity, race and culture (an-Nisaa' 4:58), and in fact the difference is not a reason for us to deny or discriminate them (al-Maaidah 5:8). Islam also recognizes that the differences are blessings bestowed by Allah the Almighty to His servant and aimed at making them interact and do good, and these differences comprise one of the factors of the pillar of faith, which is the equality of every human being (Ismail Suardi, 2012). Ethnic diversity, ethnicity and race, of course led to the diversity of cultures, lifestyles, beliefs and thought patterns and these make life so wonderful to be shared (Nazri et al., 2011). Thus, the diversity indirectly affects the overall procedures of human life either in the relationship with Allah the Almighty and relationships with other people (A.Aziz, 2000; Ramli, 2003; Sidi Gazalba 1977).

In the context of multi-cultural education in Malaysia, Islamic education is seen as a medium to integrate this diversity. This is because the goal of the teaching of Islamic Education is to produce students who have the following characteristics: a strong and resilient faith and devotion as a fortress of self defence, mastering religious obligation (far 'ain and fard kifayah), as their guidance and way of life, to practice the demands of religious obligation and to fulfil religious and moral responsibility which complements the self, and the culture (Islamic Education Syllabus KBSM 2002, Department of Islamic and Moral Education, Ministry of Education Malaysia). This is consistent with the resolution that has been achieved in the National Level Seminar on Islamic Education from 2-5 October 1995, which concluded that Islamic Education should be the core of the national education system in the implementation of an integrated education system which is based on the integration of knowledge, reason, and revelation, towards eliminating dichotomy and dualism in education.

Therefore, the Islamic Education curriculum supports the pure and superior ideals consistent with the intent and philosophy of the National Education. This is because the goals, philosophy and values brought by Islamic Education are sourced from the Quran and Hadith. In conclusion, the goals, philosophy and values in Islamic Education originating from Quran and Hadith is the basis of culture and civilization. Similarly, the functions to develop behaviours, skills, personality and outlook on life as a servant of Allah for the development of individuals, society, the environment and the country 
should be appreciated and understood by educators that this goal can be nurtured in the hearts of students.

Therefore, as educators, teachers need to understand the concept of Islamic Education itself and the cultural diversity that exists among students so that all that is intended by the philosophy of Islamic education can be achieved.

\section{The Concept of Islamic Education}

The discussion of the concept of Islamic education will encompass two main perspectives i.e. Islamic Education as a comprehensive education system or concept and Islamic Education as a subject in the existing education system (Hassan, 1995). Discussion on Islamic Education as a comprehensive system or concept include theoretical and conceptual aspects such as the concepts, processes, purposes, scopes and objectives of Islamic education and its function. While the discussion on the aspects of Islamic Education as a subject in the existing education system will be discussed in the operational context of the existing education system, such as the concept of teaching and learning Islamic Education and is limited to specific skills such as the Quran, faith, worship, morality, history and civilization.

In particular, the concept of education in Islam is referred to as an independent social framework and the prearranged work based on the traditions that has been revealed in the teachings of Islam and accepted in the sunnah of the Prophet P.B.U.H. (Gamal, 2002), as well as to train the subtle feelings of students thus forming their attitudes toward life, all actions, decisions and approaches to all kinds of knowledge, through profound spiritual and ethical values of Islam (Syed Ali Ashraf, 1994). According to Munir Muhammad Musa (1980) in Ghazali (2008), the purpose education (altarbiyah) is synonymous with the word al-ta'lim, al-adab and al-tahzib. The word al-tarbiyah originated from the word Rabbi, which means to produce, build aqliyah and khuluqiyah strengths that are based on the divine nature of the word Rab. Therefore, the process and the goal must be based on this word of faith. He also explained that Islamic Education should be based on the methodology of Islamic teachings in order to achieve the purpose to seek knowledge, skills and experience.

Tajul Ariffin (1997) and Khursid Ahmad (1979) describe the Islamic Education as spiritual and physical guidance based on the laws of Islam leading to the formation of the character according to Islamic criterion, thus the goal of education must begin with the strength of tawheed, belief and faith. In accordance with the concept as a training of the mind, physical and spiritual, then the goal of Islamic Education is to produce a highly cultured man, honourable, capable of discharging his responsibilities as a good person and a good citizen. Similarly, Abdullah Ishak (1995) provides the definition that Islamic Education is basically a process of training the mind, physical, moral, and social sense to be a good man and a good citizen.

These differ with that of Hassan Langgulung (1995), who provides analysis of the concept of Islamic Education as having two purposes:

The first is that education is public in nature, which includes spiritual, physical, emotional, social, political, cultural, economic, and other types of education relating to human life. Public education is to educate people to practice the teachings of Islam in their daily lives which include economic, cultural, social, and so on. Second, Islamic Education is limited i.e. provides commonly called religious knowledge such as; tawheed, figh, faraid, Sufism and others comprising of knowledge and knowledge on compulsory religious obligations. He also concluded that, Islamic Education is the process of preparation of young people to fill their role in the transfer of knowledge and Islamic values that are aligned with the function of humans to do good in this world and reap the rewards in the Hereafter (Hassan Langgulung, 1995). Here, Islamic Education is a process of forming the individual based on the teachings of Islam. Through this process, the human is developed to achieve a high prestige and is able to reach his duty as Allah the Almighty vicegerent on earth (alBaqarah 2:31).

In terms of process, the Islamic Education is the educational process through which children are educated with the conscious guidance which includes the mind, emotion, spirit and physical to produce a civilized human being (Muhammad Uthman El-Muhammady, 1987). Islamic Education is a learning process which includes the instruction, prohibition, the laws, the ethics and assisted by teaching materials sourced from al-Quran and al-Hadith. In other words, a person educated with Islamic Education, his mind is always thinking of something good either for himself, his family, community and nation from an Islamic perspective.

Whereas in terms of functions, Mohd. Kamal (1981) stipulates that Islamic Education serves to produce human knowledge and has parallels with the basis of the Islamic life. Knowledge is defined as the knowledge that includes the knowledge of the relationship between humans and the Creator (Allah the Almighty) which is manifested in the knowledge of faith. According to Mohd. Kamal (1988) Islamic Education is the only means in which a generation is molded. Moral education is stressed in the teaching and learning of Islamic Education. Therefore, to make it an effective 
moral education, is necessary to ensure that all elements of the education system such as curriculum, school administration, teachers and even the whole society, becomes a tool to strengthen the enrichment of students' noble values. Similarly, Ramayalus (2005) pointed out that, in terms of Islamic Education's function, it is to increase the faith and piety to Allah the Almighty, and therefore the school must work to develop the faith and piety through effective counselling and teaching.

\section{The Concept of Cultural Diversity in Islam}

Human beings by nature are created by Allah in the form of different groups and cultures and everyone must accept and respect diversity and differences as a common law of nature that will continue to occur. According to Ahmad Ali (2011), the diversity of cultures in Malaysia is in line with Islamic principles on the issue of ethnicity. In this case, Islam recognizes the dignity of every human being, regardless of ethnicity. Diversity and difference is not a factor for fragmentation and hostility (Nazri et al., 2011). We should get to know one another and assist each other to live together so that peace and prosperity can be achieved. This is in line with the word of Allah in Surah Al-Hujurat 49:13 which mean:

O mankind, indeed We have created you from male and female and made you peoples and tribes that you may know one another. Indeed, the most noble of you in the sight of Allah is the most righteous of you. Indeed, Allah is Knowing and Acquainted. (Abdullah Basmeh, 2011)

Fathi (1997) stated that this verse specifically laid the foundation of human plurality and diversity is to stimulate and promote the occurrence of interaction, cooperation and complementarily rather than isolation or conflict. This is because people as a whole are the same in Islam. Similarly, religious differences among people are accepted by Allah the Almighty. Allah the Almighty gave freedom to his creatures to make a choice whether to believe it or not. It fulfils the word of Allah in Surah an-Nisaa' 4:1, which mean:

O mankind, fear your Lord, who created you from one soul (Adam) and created from it its mate (Eve) and dispersed from both of them many men and women. And fear Allah, through whom you ask one another, and the wombs. Indeed Allah is ever, over you, an Observer.

(Abdullah Basmeh, 2011)

Sayyid Qutb (2000) also explained that the distinction language and skin colour, different habits and morals, abilities and talents are the differences that should not lead to disputes and quarrels, but these differences should lead to the nature of mutual assistance and cooperation to carry out the task and duty of humanity and complete the requirements of mankind. This is because skin colour, race, language, nation, and so on do not have any value in the consideration of Allah, because only the righteousness determines the value and advantage of mankind. With a view to the righteous as a measure of value in the consideration of Allah, then there are no more values and points of differences. Thus only righteousness became the basis for a referral human who comprise of various colours and types.

While Islam recognizes the nature of grouping people into families, tribes and nations, as the rules have been created and defined by God (Hassan Langgulung, 1995), but no one in Islam is of a higher position over another because of his wealth, status, progeny, and tribe. This is consistent with the words of the Prophet P.B.U.H.: "All men are descended from Adam, and Allah the Almighty has created Adam of clay." Allah the Almighty requires man to devote or worship, both in his relation to Allah and also in his relationships to other men so that there is peace in their lives.

For example, in the issue of the diversity of language and a mastery of the mother tongue of an ethnic group, Islamic Education teachers need to be aware that in the context of da'wah, the relationship between language and socioculture is important. This is because language remains influenced by cultural factors. Therefore, to determine the meaning of something accurately, we have to refer to cultural factors. For example, when translating, cultural elements have to be translated to fit the particular culture (Azman and Azhar, 2010). Although Arabic is selected as the language of the final revelation, the previous prophets received revelations in their own language as described in the words of Allah the Almighty in Surah Ibrahim 14:4, which mean:

"And We did not send any messenger except [speaking] in the language of his people to state clearly for them..." (Abdullah Basmeh, 2011)

This shows that Islam is for all mankind and emphasized solidarity. Linguistic diversity that exists is also as a sign of God's glory (Azman and Azhar, 2010). This is difference with Christianity which considers the diversity of language as 
a punishment. The basis of linguistic diversity is based on what Allah the Almighty says in Surah al-Baqarah 2:83, which means:

"And speak to people good [words]..."

(Abdullah Basmeh 2011)

Although Islam has made Arabic the official language of Islam, but that does not mean that other languages are not functioning, in fact Islam has recognises all of the languages used in the world. Thus the essence of the Islamic teachings can be suitable for incorporation into the use of any language whatsoever. In the context of da'wah, it is an advantage of the da'i if he can master more than one language. As recorded in the Quran about the advantages of Prophet Solomon who can master the languages of animals, spirits, and so on. The ability to capture the diversity of languages simultaneously will help to capture the culture of a people and various nations. This is because the preacher is a spokesman for Islam to man (Syed Abdurahman, 2005).

According to Mohd. Kamal Hassan (1981) as men is the slave of Allah and of the same lineage, the basis of human relations is fraternity, cooperation and the desire to help one another. Hostility, conflict and unfair competition shall be contained so that peace can be maintained in a personal relationship. In this regard, the Prophet Muhammad P.B.U.H. when he captured Mecca without bloodshed, declared to the public. Prophet P.B.U.H said that Allah has remove the arrogance that is maintained by some people in the Age of Paganism and abolished any show of loftiness attributed to heredity. For example, the Charter of Medina (Piagam Madinah) itself has guaranteed equality of rights and liabilities of all persons and also offers freedom of belief, faith and culture for all, regardless of race or religion (Mat Saad Abdul Rahman, 1999). Jews are also required to spend with Muslims during the war. They must also help in facing the enemies of the country, they are jointly liable for one another and support each other to do good and to refrain from all acts of sin (Ramble, 2003).

In conclusion, Islam has developed the concept of unity among nations and tribes that has never been seen in history before. The integration brought by Islam in addressing issues of cultural diversity has made Islam as a religion that is respected by non-Muslims. Thus the wisdom shown by the Prophet P.B.U.H. should serve as a role model for teachers in providing equal education to all students, especially those in classrooms with culturally diverse students.

\section{The Practice of Teaching of Islamic Education Based on Cultural Diversity}

The Quran states that the Prophet Muhammad P.B.U.H. was a great teacher and educator throughout the ages. As Allah the Almighty stated in Surah Al-Jumu'ah 62:2 which means

"It is He who has sent among the unlettered a Messenger from themselves reciting to them His verses and purifying them and teaching them the Book and wisdom - although they were before in clear error."

(Abdullah Basmeh 2011)

In carrying out education of the companions, the Prophet highly celebrated the distinction of each individual who learns whether those who were given the da'wah or those who inquires (Abu Guddah, 2009). He interacts with each individual based on his understanding and in line with his position. He also takes care of the feelings of people who are just beginning to learn, where the Prophet did not teach them what is taught to those who have been learning for a long time. He answered the questions posed based on the interests and circumstances of the person. Here it shows that although he strongly encourages people to go for jihad and migrate, but in this case he looks at the situation and the ability of the companions and the situations of the people who are asking. Sayyidina Abdullah bin 'Amr bin Al-As said: a man came to the Prophet, who then said:

"I gave the oath of allegiance to you for emigration and to wage jihad in order to get the reward of Allah. The Prophet said: Are any among your parents still alive? Yes, in fact they both are: the man replied. The Prophet said: Do you want the reward of Allah? The answer is: Yes! The Prophet continues by saying: Go home to your parents and serve them."

(Sahih Sunan An-Nasa'i, Kitab al-Jihad, 3103; Sahih Sunan Tirmidhi, Kitab al-Jihad, 1671)

Based on the above hadith, it is clear to us that he really took into account individual differences and needs while imparting knowledge or advice. The use of his method or celebrating the diversity of students as used by the Prophet P.B.U.H. is applicable in implementing the values of cultural diversity in the teaching of Islam and this has made the 
teaching of the Messenger effective on the companions.

The same goes to the effectiveness of teaching and learning of Islamic Education which includes motivation, needs and interests of students, ensure learning objectives, identify the level of maturity of the students, knowing the individual differences, observing the understanding, integration of existing knowledge with the origin, and the process of education as a pleasing experience for students (Maimun Aqsa Abdin Lubis et al., 2013). In the teaching of Islamic Education based on cultural diversity, the culture of the school should be driven to make the elements of culture such as values, symbols, beliefs and norms are supported and cultivated and inserted incidentally in the teaching (Federal School Inspectorate, 1993).

Atan (1980) has highlighted three important aspects in shaping the effectiveness of a teacher, which is the teachers' personality, knowledge background on the lessons to be taught and the methods or means of delivery. Meanwhile, Al-Shaibani (1979) argues that the concept of teaching and learning is a good method to help students acquire the knowledge, skills and to change attitudes and behaviour and also to instil the desired values. Teachers are also suggested to deliver lessons in accordance with the level of students' level of thinking (Al-Shaibani, 1979; AlGhazali, 1988; Ibn Khaldun 2000). Usually the existing skills and knowledge of students will become blurred and more complicated if the teacher delivers a lesson without any advance regardless to the level of students' thoughts and achievements.

In the context of the teaching of Islam, cultural diversity based instruction is a perspective and a strategy to understand the culture of students of various races and cultures in the class. Teaching based on cultural diversity is needed to help students understand the diversity of cultures in the country and they are directly involved in teaching and learning. The aim of education should be able to bring awareness to students about the existence of different cultures and language in the community and that there exists similarities in culture and language variety (Asmah Haji Omar, 1992). Mastery of the mother tongue for example, help students avoid using a language without violating the norms or rules of language that has been set by a society that uses the language. Thus a more harmonious relationship can be created during the interaction.

According to Banks (2001), education based on cultural diversity is a concept or idea related to beliefs, admission and recognition of diversity and the diversity of cultures and ethnicities that exist that affect the lifestyle, social experience and personal identity of a nation. Multicultural education aims to: (1) develop an understanding of other cultures, (2) shape attitudes towards cultural and racial diversity, and (3) a process to learn new experiences about the values and culture of others. Banks (2001; 2005), states that multi-cultural education from a variety of programmes, courses and practices carried out by educators are responses to the needs, desires and aspirations of various groups. These include gender, nationality, age, gender, marital status, race, ethnicity, social class, religion and culture.

Based on the above discussion, the teaching of Islamic Education based on students' cultural diversity can be illustrated by Figure 1.1 below:

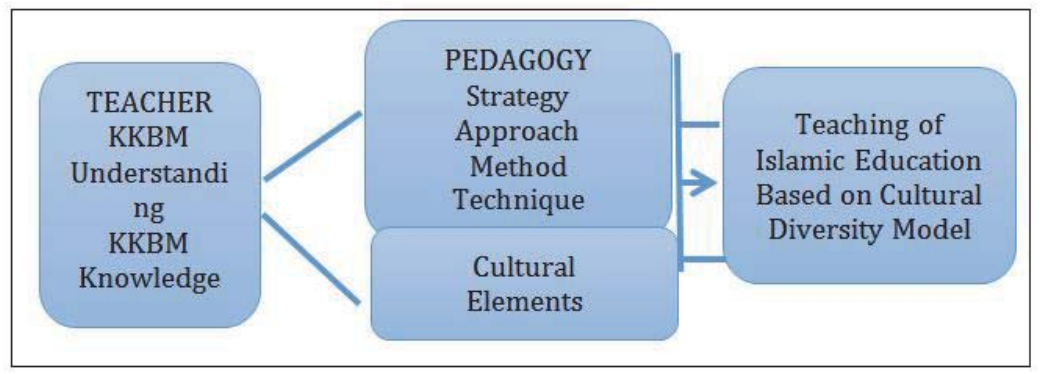

Figure 1.1: The practice of teaching of Islamic Education Based on Cultural Diversity

In terms of its importance, educational system which based on the cultural diversity is important for a developing country with a multiracial population. This step can shape and create a united people, to create and maintain the identity of the country and improve the quality of life and spirituality of the humanity as a whole. Lewis (1994) pointed out that an understanding of the culture of other ethnic groups will increase tolerance. This will make one more inclined to practice the values accepted by society. At the same time, one would know and understand more cultures.

Ibn Khaldun (2000) also explains that, in order to see the civilization of a nation, one must refer to the nation's culture, including elements of the language, lifestyle, religion and habits of dressing and practiced values. While acknowledging the existence of the tribe or nation in human society, Islam recognizes the existence of varying cultures 
and ways of life. According to Ismail Hamid (1996), some jurists argued that urf (custom) for a nation that does not conflict with the legislation can be considered as a source of law that was not already explained by the Quran and Hadith.

Education on cultural diversity is not only meets the requirements of Islam as in Surah Hujurat 49:13, but can also achieve the National Education Philosophy. Education on cultural diversity is also compatible with the Islamic concept of the issues related to ethnic relations. This is because, multi-cultural education views mankind as a macro and micro creature thus tied to each culture and ethnicity (Rina Hanipah Muslimah, 2010). Islam has always provided a procedure on relationships between Muslims and non-Muslims based on a solid, sturdy and tidy foundation which include tolerance, justice, charity and compassion that has never been seen in human history before Islam.

\section{Conclusion}

Islamic Education teachers are advised to utilise the appropriate approach in their teaching so that they can meet the needs of students comprising of different backgrounds. The wisdom of teachers in using appropriate methods will help students to understand the content of the lessons that they learned more easily. This will be helpful in our efforts to produce a balanced human being on all dimensions such as the physical, emotional, spiritual, intellectual, and social and strive to create students who can appreciate values and thus contribute to the nation. The sensitivity of teachers in implementing elements of multi-cultural education demonstrates that teachers of Islamic Education has the mindfulness and responsibility in implementing elements of multi-cultural education in the subject of Islamic Education. Elements of various cultures should be incorporated into the curriculum to ensure the effectiveness of teaching students who are culturally diverse.

\section{References}

Al-Quran al-Karim. Tafsir pimpinan Ar-Rahman kepada pengertian al-Quran: (30 juz). Ed. Ke 12. Kuala Lumpur: Darulfikir. Abdullah Ishak. (1995). Pendidikan Islam Dan Pengaruhnya Di Malaysia. Kuala Lumpur: Dewan Bahasa Dan Pustaka.

Abu Ghuddah. (2009). Rasulullah Pendidik Terulung: 40 Teknik Mengajar Rasulullah. Terj Hj Shuhadak Mahmud. Negeri Sembilan: AlAzhar Media.

Ahmad Ali Seman. (2011). Keberkesanan Modul Pengajaran Dan Pembelajaran Sejarah Berteraskan Perspektif Kepelbagaian Budaya Terhadap Pembentukan Integrasi Nasional. Tesis Dr.Fal, Fakulti Pendidikan, Universiti Kebangsaan Malaysia.

Al-Ghazali, A. M. B. A., . (1988). Ihya' Ulumuddin Jiwa Agama.Terj.Tk.Hj Ismail Yaakub Sh. Kuala Lumpur: Victory Ajensi.

Asmah Hj Omar. (1992). Kajian Dan Pembangunan Bahasa Melayu. Kuala Lumpur: Dewan Bahasa Dan Pustaka.

Banks, J. A. (2001). Cultural Diversity and Education: Foundations, Curriculum, and Teaching. 4th ed. Boston: Allyn \& Bacon.

Fathi Osman. (1997). Concepts of the Quran: A Topical Reading. Kuala Lumpur: Angkatan Belia Islam Malaysia.

Gamal Abdul Nasir Zakaria. (2002). Tauhid Asas Pendidikan Islam. Prosiding Wacana Pendidikan Islam (Siri 1). Kurikulum Bersepadu Pendidikan Islam Menghadapi Cabaran era Globalisasi.

Ghazali Basri. (1993). Utilising Religious for the Basis of Integrated Education Curriculum in Multi-Faith and Multi-Cultural Society. DIm. Mohd Zahid Noordin (pnyt.). An Integrated Education System in a Multi-Faith and Multi-Cultural Country, hlm. 1-11. Kuala Lumpur: Angkatan Belia Islam Malaysia (ABIM).

Ghazali Basri. (2003). Pendidikan Silang Budaya Menurut Perspektif Islam:Satu Pandangan Awal. Jurnal Pendidikan Islam 1(3): hlm:113.

Hassan Langgulung. (1995). Pendidikan Islam Dan Peralihan Paradigma. Shah Alam: Hizbi.

Ibn Khaldun. (2000). Mukaddimah Ibn Khaldun. Terj Dewan Bahasa Dan Pustaka Malaysia. Kuala Lumpur: Kementerian Pendidikan Malaysia.

Ismail Hamid. (1996). Pengajian Kebudayaan Melayu Dari Perspektif Islam: Satu Perbincangan Awal. Dlm. Wan Hashim Wan Teh. \& Mahayudin Yahaya (pnyt.). Sains Sosial Dari Perspektif Islam, Bangi: Universiti Kebangsaan Malaysia.

Ismail Suardi Wekke. (2012). Amalan Pengajaran Dan Pembelajaran Bahasa Arab Di Pasentren Immim Makkasar, Indonesia. Tesis Fakulti Pendidikan, Universiti Kebangsaan Malaysia.

James, A. B. \& Cherry, A. M., Banks. (2005). Mutlicultural Education Issues and Perspectives. United States of America: John Wiley \& Sons, Inc.

Khursid Ahmad. (1979). Prinsip-Prinsip Pendidikan Islam. Kuala Lumpur.

Mat Saad Abdul Rahman. (1999). Kedudukan Bukan Islam Di Dalam Sejarah Pemerintahan Islam. DIm. Mat Saad Abdul Rahman (pnyt.). Prinsip-Prinsip Pemerintahan Dalam Masyarakat Majmuk, hlm. 83-118. Kuala Lumpur: Institut Kefahaman Islam Malaysia.

Mohd. Kamal Hassan.(1981). Konsep Pendidikan Islam. Kuala Lumpur: Yayasan Dakwah Islamiah.

Mohd. Kamal Hassan. (1988). Pendidikan Dan Pembangunan: Satu Perspektif Bersepadu. Kuala Lumpur: Nurin Enterprise.

Mok Soon Sang. (2012). Psikologi Pendidikan. Subang Jaya: Penerbitan Multimedia.

Muhammad Uthman El-Muhammady. (1987). Islam, Peribadi, Tarbiah Dan Institusi. Kota Bharu: Majlis Ugama Islam Kelantan. 
Nazri Muslim, Nik Yusri Musa. (2011). Hubungan Etnik Di Malaysia Dari Perspektif Islam. Kajian Malaysia 29(1): 1-28.

Najeemah Mohd Yusof. (2005). Multicultural Education Practice among Teachers in National Secondry Schools: A Case Study in Kedah. Jurnal Pendidik dan Pendidikan 20(97-111.

Ramayulis. (2005). Metodologi Pendidikan Agama Islam. Jakarta: Kalam Mulia.

Ramli Awang.(2003). Islam Alternatif Perpaduan Sejagat. Johor Darul Ta'zim: Universiti Teknologi Malaysia.

Rina Hanipah Muslimah. (2010). Analisis Nilai-Nilai Pendidikan Multikultural Dalam Teks Mata Pelajaran Pendidikan Agama Islam Sma Kelas X. Tesis Sarjana Strata Satu Pendidikan Islam, Fakultas Tarbiyah dan Keguruan UIN Sunan Kalijaga Yogyakarta.

Segawa, N. (2007). Malaysia's1996 Education Act:The Impact of a Multiculturalism-Type Approach on National Integration. Journal of Social Issues in Southeast Asia 22(1): 30-56.

Shamsul Amri Baharuddin. (2007). Modul Hubungan Etnik. Kuala Lumpur: Maskh Sdn.Bhd.

Sidi Gazalba (1977). Pandangan Islam Tentang Kesenian. Kuala Lumpur: Pustaka Antara.

Sayid Qutb. (2000). Tafsir Fi Zilallil Qura'an. Terjemahan Yusoff Zaky Hj Yacob. Kuala Lumpur. Pustaka Aman Press

Syed Abdurahman Syed Hussin. (2005). Pendekatan Taghrib Dan Tarhib Dalam Penyampaian Dakwah. Jurnal Usuluddin 21(117-138).

Syed Ali Ashraf. (1994). Horizon Baru Dalam Pendidikan Islam. Kuala Lumpur: Dewan Bahasa Dan Pustaka.

Tajul Ariffin Bin Noordin. (1997). Pendidikan Dan Pembangunan Manusia: Satu Pendekatan Bersepadu. Konvensyen Kebangsaan Pendidikan Moral dan Nilai dam Pembangunan Manusia ke Arah Pembentukan Acuan Pembangunan Negara. Anjuran Universiti Kebangsaan Malaysia. Fakulti Pendidikan,

Yussof, A. S. (2010). Idea-Idea Pendidikan Berkesan Al-Ghazali \& Konfusius. Bangi: Universiti Kebangsaan Malaysia. 
